\title{
Gentiana macrophylla Pall (Gentianaceae) extract exerts protective effects against osteoporosis in mice
}

\author{
Teng Gong ${ }^{1-3}$, Xue-Tao Su ${ }^{1 *}$, Qun Xia ${ }^{1}$, Jing-Gui Wang ${ }^{1}$ \\ ${ }^{1}$ Department of Orthopedic Surgery, The Affiliated Hospital of Logistics College of Chinese People's Armed Police Force, No. \\ 220 Chenglin Road, Dongli District, Tianjin City, 300162, ' Department of Spinal Surgery, Tianjin Hospital, Clinical Medical \\ College of Tianjin Medical University, No. 406 Jiefang Nan road, Hexi District, Tianjin City, 300211, ${ }^{3}$ Post-doctoral Station, \\ Tianjin Medical University, No. 22 Qixiang Tai Road, Tanjin City, 300070, China
}

*For correspondence: Email: skymberlysoul@yahoo.com; Tel/Fax: 0086-022-60578952

\begin{abstract}
Purpose: To evaluate the anti-osteoporotic effect of $G$. macrophylla extract in a mice model. Methods: Antioxidant activity was determined by 2, 2-diphenyl-1-picrylhydrazyl (DPPH) for radical scavenging, nitro-blue tetrazolium (NBT) reducing, and ferric reducing antioxidant power (FRAP) assays using standard biochemical procedures. The expression of some bone-related genes was measured by quantitative real-time polymerase chain reaction (qTR-PCR). Phytochemical analysis was carried out by liquid chromatography-mass spectrometry (LC/MS).

Results: The extract exhibited strong antioxidant activity as evident from DPPH, NBT and FRAP data, with half-maximal inhibitory concentration $\left({ }^{\prime} C_{50}\right)$ values of 275,262 and $180 \mu \mathrm{g} / \mathrm{ml}$, respectively. The antioxidant activity was concentration-dependent. The results showed that the extract restored bone characteristics by suppressing bone resorption through induction of expressions of several boneassociated genes. The results from phytochemical analyses showed the presence of loganic acid, swertiamarin, sweroside, gentiopicroside, gentesin and isogentesin.

Conclusion: These results indicate that the extract may be beneficial in the treatment of osteoporosis.
\end{abstract}

Keywords: Gentiana macrophylla, Osteoporosis, Bone mass, Loganic acid, Swertiamarin, Sweroside, Gentiopicroside, Gentesin

\footnotetext{
This is an Open Access article that uses a funding model which does not charge readers or their institutions for access and distributed under the terms of the Creative Commons Attribution License (http://creativecommons.org/licenses/by/4.0) and the Budapest Open Access Initiative (http://www.budapestopenaccessinitiative.org/read), which permit unrestricted use, distribution, and reproduction in any medium, provided the original work is properly credited.
}

Tropical Journal of Pharmaceutical Research is indexed by Science Citation Index (SciSearch), Scopus, International Pharmaceutical Abstract, Chemical Abstracts, Embase, Index Copernicus, EBSCO, African Index Medicus, JournalSeek, Journal Citation Reports/Science Edition, Directory of Open Access Journals (DOAJ), African Journal Online, Bioline International, Open-J-Gate and Pharmacy Abstracts

\section{INTRODUCTION}

Osteoporosis is one of the bone degenerative disorders associated with high bone fragility and lower bone mass often leading to bone fractures [1]. It has been reported that the incidence of osteoporosis increases with increase in age, which implies that the disease is more common during old age [2]. Currently, the main option for prevention of osteoporosis is hormone replacement therapy (HRT). However, with advancements in science and technology, HRT has now been reported to be associated with risk of development of breast and ovarian cancers in post-menopausal women [3-5]. Therefore, there is a need to develop alternative, effective, efficient and more viable treatment options for osteoporosis. In this context, it is believed that 
Chinese herbal medicine may prove beneficial in treatment and management of osteoporosis.

Gentiana macrophylla belongs to family Gentianaceae and it is considered an important medicinal herb. It is popularly known as "Qin Jiao" and it is abundant mostly in China and Siberia. The roots of $G$. macrophylla taste bitter due to the presence of some phyto-constituents. Studies have shown that G. macrophylla extracts possess laxative properties, and its ethanol extract exhibits broad range antimicrobial activity [6]. Often, G. macrophylla, is used in combination with other Gentiana species for maintenance of healthy sinus, and for treating rheumatoid arthritis and osteoporosis [7]. The plant is also used in Chinese herbal medicine for the management of diabetes, osteoporosis and rheumatism [8].However, till date, the use of $G$. macrophylla in the prevention of osteoporosis has not been validated scientifically. This study was therefore designed to evaluate the potential of G. macrophylla for prevention of osteoporosis. Moreover, phytochemical analysis of the extract was carried out to putatively identify the phytochemical constituents potentially responsible for its protective effect.

\section{EXPERIMENTAL}

\section{Collection of plant material and preparation of extract}

The roots of G. macrophylla were harvested from their natural environment in Dongli District, Tianjin, China. The plant material was identified by Teng Gong at Post-doctoral station, Tianjin Medical University and a voucher specimen was deposited in Tianjin Medical University herbarium (voucher no. TMU/GM/09854/2016). The roots were dried at room temperature, ground to a fine powder $(10 \mathrm{~kg})$ and then extracted at least 3 times with $90 \%$ methanol. The extract was then concentrated under vacuum to yield the final extract weighing $2.5 \mathrm{~kg}$. The extract was stored at $4{ }^{\circ} \mathrm{C}$ prior to further usage.

\section{Evaluation of antioxidant activities}

The antioxidant activities of the methanol extract of $G$. macrophylla were assessed through DPPH radical scavenging, NBT reduction, and FRAP assays as described previously [9].

\section{Animal groups}

Three month-old female virgin mice were obtained from Tianjin Medical University. The animals were kept in well-ventilated rooms with controlled setting of light/dark cycle, temperature of $24 \pm 2{ }^{\circ} \mathrm{C}$ and humidity of $40-60 \%$. The study was approved by the Animal Ethics Committee of Tianjin Medical University under approval number C24/TJM/0987/2016. International guidelines were followed in carrying out the animal studies [10]. The mice were subjected to either laparotomy or closure $(n=20)$, or laparotomy followed by bilateral oophorectomy ( $\mathrm{n}$ $=30$ ). They were divided into five groups. Mice that underwent laparotomy and closure formed Group I (received normal saline, $\mathrm{n}=10$ ) or Group II (which received $300 \mathrm{mg} / \mathrm{kg}$ of the extract, $n=10$ ), while those that underwent laparotomy and bilateral oophorectomy formed Group III (given normal saline). Group IV mice (n = 10) were given $150 \mathrm{mg} / \mathrm{kg}$ of the extract, while Group V mice $(n=10)$ received $300 \mathrm{mg} / \mathrm{kg}$ of the extract. To ensure that the mice received the proper dose of the extract, the extract was administered via a gastric tube. After 12 weeks of extract administration, urine was collected and then the mice were sacrificed by deep anesthesia with isoflurane. Blood was also withdrawn and serum was isolated from the blood as described previously [11]. The tibias and uteri were excised and stored at $-80{ }^{\circ} \mathrm{C}$ for further investigation.

\section{Serum and urine analysis}

The serum and urine analysis of the mice from all groups were carried out in line with standard protocols. Alkaline phosphatase (ALP), serum calcium (Ca), phosphorus $(\mathrm{P})$ and urine $\mathrm{Ca}, \mathrm{P}$ and creatinine levels were determined as reported previously [12].

\section{RNA isolation and RT-PCR}

Total RNA was isolated from the tibia by TRIzol as per the manufacturer's instructions, and cDNA was synthesized by cDNA synthesis (Invitrogen) using $3 \mu \mathrm{g}$ of the isolated RNAs in $20 \mu \mathrm{L}$ reaction, with random primers. The Rt-PCR reaction conditions were: one cycle at $95{ }^{\circ} \mathrm{C}$ for $4 \mathrm{~min}, 27$ cycles at $95{ }^{\circ} \mathrm{C}$ for $40 \mathrm{sec}, 55^{\circ} \mathrm{C}$ for $30 \mathrm{sec}$, and $72^{\circ} \mathrm{C}$ for $40 \mathrm{sec}$. The primers used in the study were as described previously $[13,14]$.

\section{Phytochemical analysis}

Phytochemical analysis was carried out by dissolving the extracts in methanol and filtering through nylon HPLC filters $(0.22 \mu \mathrm{m})$. Liquid chromatography-mass spectrometry(LC/MS) apparatus Nexera UHPLC (130 MPa) connected to Shimadzu MS-8030 was employed for this study. Enable RP-C18 column $(250 \mathrm{~mm} \times 4.6$ $\mathrm{mm}, 5 \mu \mathrm{M}$ ) was used and the injection volume was $2.5 \mu \mathrm{L}$ at a flow rate of $0.3 \mathrm{ml} / \mathrm{min}$. Mobile 
phase $A$ was water and acetonitrile in a volume ratio of $1: 1$, while mobile phase $B$ was acetic acid $(0.1 \%)$. The initially column temperature was $75^{\circ} \mathrm{C}$. The mass chromatograms were obtained in both positive and negative ionization modes. The scan range was between 100 and $1000 \mathrm{~m} / \mathrm{z}$.

\section{Statistical analysis}

Data are presented as mean \pm SD. Statistical analysis was done with Student's t-test and differences were considered significant at ${ }^{*} p<$ $0.01,{ }^{* *} p<0.001$ and ${ }^{* * *} p<0.0001$.

\section{RESULTS}

\section{Antioxidant activity of G. macrophylla extract}

The results of this study revealed that in all the three assays $G$. macrophylla exhibited significant antioxidant activity. This antioxidant activity was also found to exhibit a dose-dependent trend (Figure $1 \mathrm{~A}$ to $1 \mathrm{C}$ ). At $500 \mu \mathrm{g} / \mathrm{ml}$, the inhibition of the extract was $75 \%$ in case of DPPH assay, while for NBT assay, the inhibition was $72 \%$. In the FRASP assay, the absorbance increased from 0.36 at $100 \mu \mathrm{g} / \mathrm{ml}$, to 0.94 at $500 \mu \mathrm{g} / \mathrm{ml}$, indicating the antioxidant potential of the extract. The $I_{50}$ values of the extract for DPPH, NBT and FRAP assays were 275,262 , and $180 \mu \mathrm{g} / \mathrm{ml}$, respectively.

\section{Effect of G. macrophylla extract on body weight, uterus index, and some serum and urine parameters}

The results indicated that there was significant weight gain in group III mice, when compared to the group I mice (Table 1), while there was no significant difference between the weight of control (group I) mice and control mice receiving the $300 \mathrm{mg} / \mathrm{kg}$ extract (group II). However, in groups IV and V mice which received 150 and $300 \mathrm{mg} / \mathrm{kg}$ of the extract, significant reduction in weight was seen, when compared to the model animals (group III). Interestingly, the uterus index was significantly lower in group III group, when compared to group I (Table 1). However no significant changes were observed in group I mice. Administration of extract at doses of 150 $\mathrm{mg} / \mathrm{kg}$ (group IV) and $300 \mathrm{mg} / \mathrm{kg}$ (group V) led to a significant increase in uterus index. In addition, ovariectomy of the mice (group III) augmented urinary calcium .excretion and serum ALP level. This was in tandem with reduction in serum $\mathrm{Ca}$ and $P$ levels, when compared to the sham group (group I). However, administration of 150 and $300 \mathrm{mg} / \mathrm{kg}$ of the extract reversed the ovariectomy-induced changes in serum $\mathrm{Ca}$ and $\mathrm{P}$ levels, and urinary $\mathrm{Ca}$ in mice $(p<0.05)$. The $\mathrm{G}$.
A

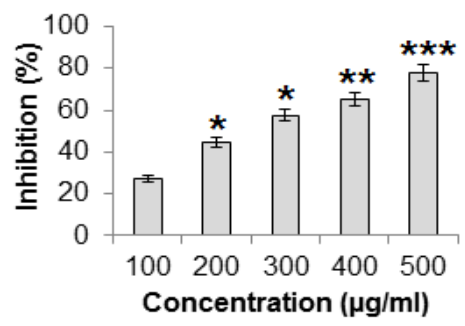

B

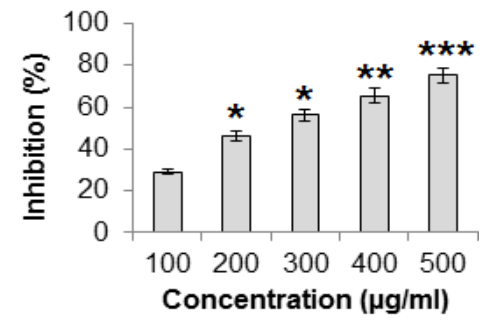

C

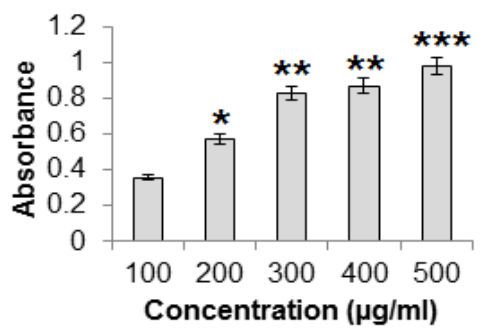

Figure 1: Antioxidant activity of methanol extract of G. macrophylla by (A) DPPH assay; (B) NBT assay, and (C) FRAP assay. The assays were carried out in triplicates and the values were considered significant at ${ }^{*} p<0.01$, ${ }^{* *} p<0.001$ and ${ }^{* * *} p<0.0001$

Table 1: Effect of G. macrophylla extract on uterus index, serum ALP, and serum and urinary levels of Ca and $P$. The experiments were repeated thrice in triplicates and the values were presented as mean \pm SD

\begin{tabular}{lccccccc}
\hline Group & $\begin{array}{c}\text { Weight } \\
\mathbf{( g )}\end{array}$ & $\begin{array}{c}\text { Uterus index } \\
(\mathbf{m g} / \mathbf{g})\end{array}$ & $\begin{array}{c}\text { Serum ALP } \\
\mathbf{( U / L )}\end{array}$ & $\begin{array}{c}\text { Serum Ca } \\
(\mathbf{m g} / \mathbf{d} \mathbf{l})\end{array}$ & $\begin{array}{c}\text { Serum P } \\
(\mathbf{m g} / \mathbf{d l})\end{array}$ & $\begin{array}{c}\text { Urine } \\
\mathbf{C a} / \mathbf{C r} \\
(\mathbf{m g} / \mathbf{m g})\end{array}$ & $\begin{array}{c}\text { Urine P/Cr } \\
(\mathbf{m g} / \mathbf{m g})\end{array}$ \\
\hline I & $1.7 \pm 0.05$ & $3.1 \pm 0.04$ & $70.4 \pm 3.21$ & $10.3 \pm 0.51$ & $9.1 \pm 0.75$ & $0.27 \pm 0.02$ & $4.53 \pm 0.22$ \\
II & $1.6 \pm 0.03$ & $3.2 \pm 0.02$ & $68.4 \pm 2.78$ & $10.6 \pm 0.76$ & $9.0 \pm 0.66$ & $0.25 \pm 0.01$ & $4.55 \pm 0.32$ \\
III & $2.5 \pm 0.07$ & $1.4 \pm 0.05$ & $90.1 \pm 4.10$ & $7.6 \pm 0.55$ & $7.4 \pm 0.34$ & $0.38 \pm 0.01$ & $5.71 \pm 0.44$ \\
IV & $2.1 \pm 0.04$ & $2.2 \pm 0.03$ & $78.3 \pm 3.64$ & $8.4 \pm 0.95$ & $8.2 \pm 0.42$ & $0.32 \pm 0.02$ & $4.87 \pm 0.54$ \\
V & $1.8 \pm 0.03$ & $2.4 \pm 0.06$ & $74.5 \pm 2.76$ & $9.1 \pm 0.80$ & $8.7 \pm 0.52$ & $0.29 \pm 0.01$ & $4.62 \pm 0.43$ \\
\hline
\end{tabular}


macrophylla extract administration at both doses significantly reduced serum ALP level in the OVX mice (Table 1). Furthermore, administration of the extract significantly $(p<0.05)$ decreased the urinary $\mathrm{Ca}$ and increased serum $\mathrm{Ca}$ level.

\section{Effect of G. macrophylla extract on the expression of bone-specific genes}

The results of this study revealed that the expression levels of Cbfa1was down-regulated whereas the expression of Ctsk was upregulated in tibia of mouse in response to ovariectomy. However administration of 150 and $300 \mathrm{mg} / \mathrm{kg}$ extract doses (groups IV and V) led to significant $(p<0.01)$ enhancements in the
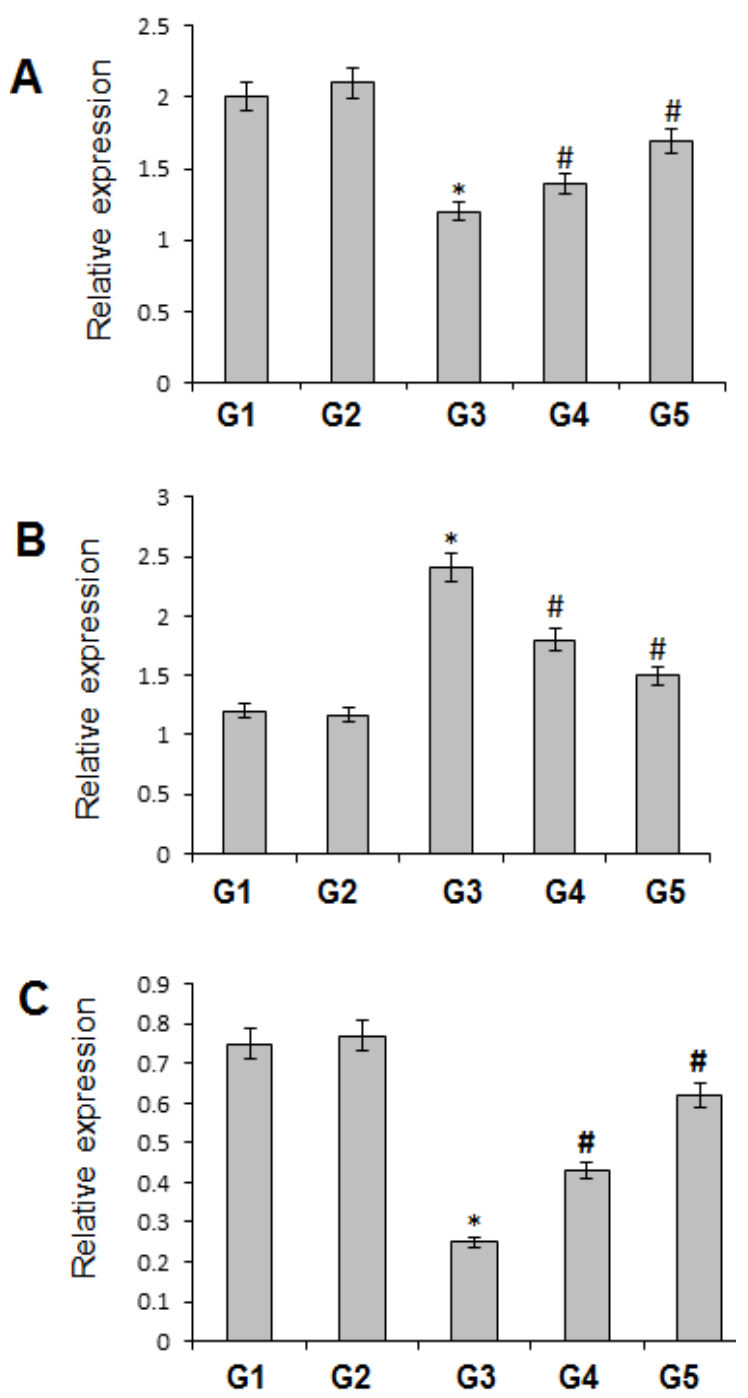

Figure 2: Effect of $G$. macrophylla extract on the expression of: (A) Ctsk, (B)Cbfa1, and (C)OPG/RANKL as determined using quantitative RT$P C R$. Data are presented as mean \pm SD. The values were considered at ${ }^{*} p<0.01 \mathrm{G} 3$ vs G1 and ${ }^{\#} p<0.01$ G3Vs G4. G1 to G5 represent groups 1 to 5

Following literature survey and $\mathrm{m} / \mathrm{z}$ ratio, six compounds were putatively identified. These transcript of Cbfa1, and suppression of Ctsk mRNA expression in mouse tibia in response to ovariectomy (Figures $2 \mathrm{~A}$ and $2 \mathrm{~B}$ ). The results indicate that administration of extracts at doses of 150 and $300 \mathrm{mg} / \mathrm{kg}$ reversed OVX-prompted changes in the expression of OPG/RANKL in tibia (Figure 2B).

\section{Phytochemical analysis of G. macrophylla extract}

To gain understanding about the phytoconstituents of $G$. macrophylla that nay be potentially responsible for its protective effects, LC/MS analysis was carried out (Figure 3).

included loganic acid, swertiamarin, sweroside, gentiopicroside, gentesin and isogentesin (Figure $4)$.

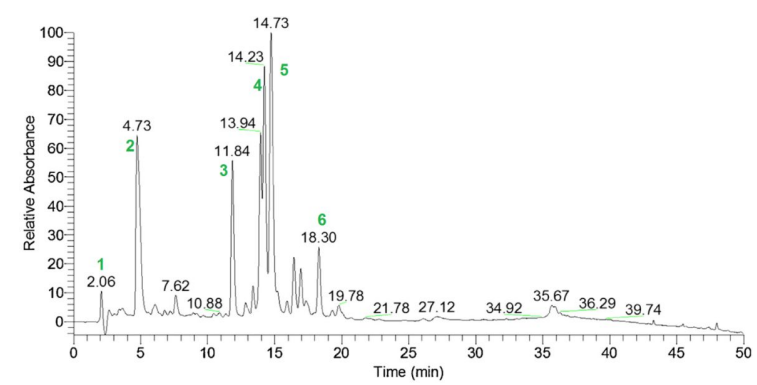

Figure 3: LC/MS chromatogram of the methanol extract of G. macrophylla.Peaks1-6 were tentatively identified as shown in Figure 4
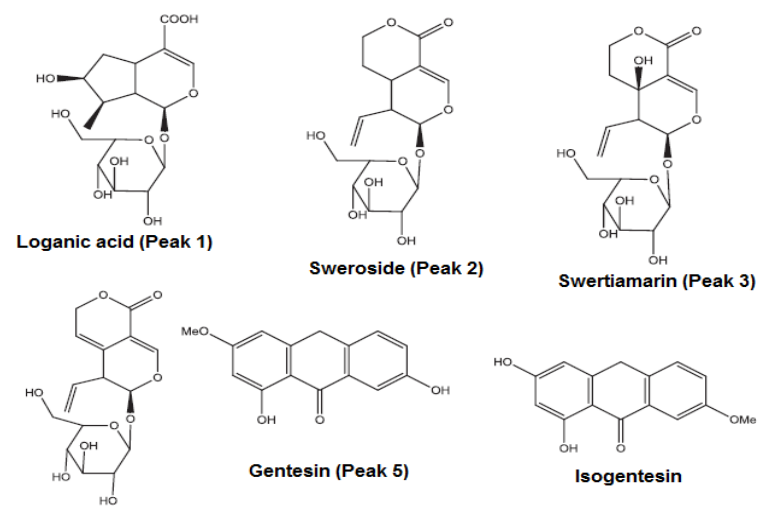

Gentiopicroside (Peak 4)

Figure 4: Structure of the compounds identified by LC/MS analysis. The peak numbers are as per chromatogram shown in Figure 3

\section{DISCUSSION}

Osteoporosis is a one of the lethal bone degenerative diseases which cause bone fragility [1]. Reactive oxygen species (ROS) have been implicated in the onset and development of different diseases and disorders including 
osteoporosis. Currently, there are limited treatments available for osteoporosis, but these treatments are associated with lots of side effects. In this context, Chinese medicine is believed to be beneficial in the treatment of osteoporosis [14]. This study was therefore directed towards evaluation of the protective effects of G. macrophylla in experimental mice models of osteoporosis. Since ROS have been implicated in the etiology of osteoporosis, the antioxidant activity of the extract was evaluated through three different assays [15]. The results of the study indicated that G. macrophylla exhibited antioxidant activity in all the three assays viz DPPH, NBT and FRAP. These results are in agreement with previous reports wherein several Gentiana spp. were shown to exhibit antioxidant activities [16].

The effect of $G$. macrophylla was also evaluated in vivo in mice models and it was observed the G. macrophylla extract reversed the ovariectomyinduced alterations in blood and serum composition. Several plant extracts have been reported to cause such effects in vivo in osteoporosis mice models [17].In addition, the extract also caused alterations in the expressions of several bone associated genes. It was observed that G. macrophylla extract enhanced the transcription of Cbfa1 mRNA and cathepsin K mRNA, and increased the ratio of OPG/RANKL mRNA expression in the tibia. The results are well supported by a previous study wherein Sambucus williamsii exhibited similar effects [18]. The results of LC/MS analysis showed the presence of several compounds which may be potentially responsible for the protective effects of the extract. These results are consistent with previous findings on other Gentiana species [19].

\section{CONCLUSION}

Methanol extract of G. macrophylla was found to exhibit significant antioxidant activity. In vivo studies showed that this extract exerted protective effects in mice model of osteoporosis. Therefore, G. macrophylla extract may be beneficial in the treatment of osteoporosis.

\section{DECLARATIONS}

\section{Acknowledgement}

We acknowledge the Department of Orthopedic Surgery of The Affiliated Hospital of Logistics College of Chinese People's Armed Police Forces, Tianjin City for providing facilities for this study.

\section{Conflict of interest}

No conflict of interest is associated with this work.

\section{Contribution of authors}

The authors declare that this work was done by the authors named in this article and all liabilities pertaining to claims relating to the content of this article will be borne by them. Teng Gong did all the experiments under supervision of Xue-Tao Su. Qun Xia and Jing-Gui Wang collected data and offer help for analysis of the data as well.

\section{REFERENCES}

1. Zhang JK, Yang L, Meng GL, Fan J, Chen JZ, He QZ, Chen S, Fan JZ, Luo ZJ, Liu J. Protective effect of tetrahydroxystilbene glucoside against hydrogen peroxide-induced dysfunction and oxidative stress in osteoblastic MC3T3-E1 cells. Euro J Pharmacol 2012; 689: 31-37.

2. Johnell O, Kanis JA. An estimate of the worldwide prevalence and disability associated with osteoporotic fractures. OsteoporosInt2006; 17: 1726-1733.

3. Roux C. Osteoporosis and hormone replacement therapy. Presse Med. 2005; 34: 379-384.

4. Ryan PJ, Harrison R, Blake GM, Fogelman I. Compliance with hormone replacement therapy (HRT) after screening for post-menopausal osteoporosis. BJOG: Int J Gynaecol Obstet 1992; 99: 325-328.

5. Nelson HD, Humphrey LL, Nygren P, Teutsch SM, Allan JD. Postmenopausal hormone replacement therapy: scientific review. Jama 2002; 288: 872-881.

6. Jia N, Li Y, Wu Y, Xi M, Hur G, Zhang X, Cui J, Sun W, Wen $A$. Comparison of the anti-inflammatory and analgesic effects of Gentiana macrophylla Pall and Gentiana straminea Maxim., and identification of their active constituents. J Ethanopharmacol 2012; 144: 638645 .

7. Yu F, Yu F, Li R, Wang R. Inhibitory effects of the Gentiana macrophylla (Gentianaceae) extract on rheumatoid arthritis of rats. J Ethanopharmacol 2004; 95(1): 77-81.

8. Jia N, Chu W, Li Y, Ding L, Duan J, Cui J, Cao S, Zhao $C, W u Y$, Wen A. Iridoid glycosides from the flowers of Gentiana macrophylla Pall. ameliorate collagen-induced arthritis in rats. J Ethanopharmacol 2016; 189: 1-9.

9. Baba SA, Malik AH, Wani ZA, Mohiuddin T, Shah Z, Abbas N, Ashraf N. Phytochemical analysis and antioxidant activity of different tissue types of Crocus sativus and oxidative stress alleviating potential of saffron extract in plants, bacteria, and yeast. S Afr J Bot 2015; 99: 80-87.

10. McGrath JC, Drummond GB, McLachlan EM, Kilkenny C, Wainwright $C L$. Guidelines for reporting experiments 
involving animals: the ARRIVE guidelines. British $J$ Pharmacol, 2010; 160: 1573-6.

11. Teahan O, Gamble S, Holmes E, Waxman J, Nicholson JK, Bevan C, Keun HC. Impact of analytical bias in metabonomic studies of human blood serum and plasma. Analytical Chem 2006; 78: 4307-18.

12. Beckonert O, Keun HC, Ebbels TM, Bundy J, Holmes E, Lindon JC, Nicholson JK. Metabolic profiling, metabolomic and metabonomic procedures for NMR spectroscopy of urine, plasma, serum and tissue extracts. Nat Protoc 2007; 2: 2692-703.

13. Trouvin AP, Goeb V. Receptor activator of nuclear factor$\kappa B$ ligand and osteoprotegerin: maintaining the balance to prevent bone loss. Clin Interv Aging 2010; 5: 345-354.

14. Zhang $H$, Xing WW, Li YS, Zhu Z, Wu JZ, Zhang QY, Zhang W, Qin LP. Effects of a traditional Chinese herbal preparation on osteoblasts and osteoclasts. Maturitas 2008; 61: 334-339.

15. Baba SA, Malik SA. Evaluation of antioxidant and antibacterial activity of methanol extracts of Gentiana kurroo royle. Saudi J BiolSci 2014; 21: 493-498.
16. Pereira JV, Modesto-Filho J, de FAgra M, Barbosa-Filho JM. Plant and plant-derived compounds employed in prevention of the osteoporosis. Acta Farm Bonaer 2002; 21: 223-34.

17. Zhang $Y, L i Q, L i X$, Wan HY, Wong MS. Erythrina variegata extract exerts osteoprotective effects by suppression of the process of bone resorption. Br J Nutr 2010; 104: 965-971.

18. Zhang $Y, L i Q$, Wan $H Y$, Xiao HH, Lai WP, Yao XS, Wong MS. Study of the mechanisms by which Sambucus williamsii HANCE extract exert protective effects against ovariectomy-induced osteoporosis in vivo. Osteoporosis Int 2011; 22: 703-709.

19. Wani BA, Ramamoorthy D, Rather MA, Arumugam N, Qazi AK, Majeed R, Hamid A, Ganie SA, Ganai BA, Anand $R$, et al., . Induction of apoptosis in human pancreatic MiaPaCa-2 cells through the loss of mitochondrial membrane potential $\left(\Delta \Psi_{m}\right)$ by Gentiana kurroo root extract and LC-ESI-MS analysis of its principal constituents. Phytomed 2013; 20: 723-33. 